\title{
Plasma gonadotrophins and oestradiol during oestrus in the cow
}

\author{
Hilary Dobson \\ Department of Veterinary Clinical Studies, University of Liverpool, \\ 'Leahurst', Neston, Wirral, L64 7TE, U.K.
}

\begin{abstract}
Summary. $\mathrm{LH}$ values between -2 and $+4 \mathrm{~h}(0 \mathrm{~h}=\mathrm{LH}$ peak) were higher than baseline. FSH values were also raised at this time and between +16 and $+30 \mathrm{~h}$. Oestradiol values between -20 and $0 \mathrm{~h}$ were higher than during +4 to $+20 \mathrm{~h}$.
\end{abstract}

Plasma FSH levels during the bovine oestrous cycle have been measured (Akbar, Reichert, Dunn, Kaltenbach \& Niswender, 1974; Derivaux, Ectors, Hendrick \& Franchimont, 1974; Schams \& Schallenberger, 1976), but details of the changes in plasma oestradiol concentration and those of LH and FSH during the oestrous period have not been reported. The following investigation was undertaken to define the temporal relationship between these hormones. Progesterone concentrations are known to remain basal $(<0.5 \mathrm{ng} / \mathrm{ml}$ ) throughout oestrus (Dobson, Cooper \& Furr, 1975).

\section{Materials and Methods}

Six Friesian heifers, $18-36$ months old, were bled $(20 \mathrm{ml})$ from indwelling jugular vein catheters every $2 \mathrm{~h}$ for 3 days, starting 1 day before oestrus. Plasma was obtained immediately by centrifugation and stored at $-15^{\circ} \mathrm{C}$. The radioimmunoassays, used without modification, have been described in detail elsewhere. In the LH assay (Dobson et al., 1975) the antibody to bovine LH was raised in a horse by Dr R. B. Snook. The only significant cross-reaction was with TSH $(90 \%)$. Purified bovine LH (LER $1072 / 2$ ) was used as the ${ }^{125} \mathrm{I}$-labelled preparation. The sensitivity of the method was $0.2 \mathrm{ng}$ with interand intra-assay coefficients of variation of 10.6 and $8.3 \%$ respectively. The plasma results are expressed as ng equivalents of NIH-LH-B8/ml. For the FSH assay (Dobson, 1978) an antibody to rat FSH (S6: obtained from NIAMDD) was used. The only significant cross-reaction was $5 \%$ with TSH. Purified bovine FSH (LER-1695-2) was used as the ${ }^{125}$ I-labelled preparation. The sensitivity of the method was 4 ng with inter- and intra-assay coefficients of variation of 15.5 and $14.5 \%$ respectively. The plasma results are expressed as ng equivalents of $\mathrm{NIH}-\mathrm{FSH}-\mathrm{Bl} / \mathrm{ml}$. The oestradiol assay (Dobson \& Dean, 1974) utilized an antibody $\left(\mathrm{R}_{2} \mathrm{~B}_{2}\right)$ raised against oestradiol-6-(O-carboxymethyl) oximebovine serum albumin which had no cross-reactions of $>2 \%$ with any other oestrogen known to occur in the cow. The sensitivity of the method was $<10 \mathrm{pg}$ with inter- and intra-assay coefficients of variation of 12.5 and $7.8 \%$, respectively.

\section{Results}

The changes of LH, FSH and oestradiol concentrations in 6 heifers in relation to the time of maximum LH concentration $(0 \mathrm{~h})$ are shown in Text-fig. 1 . The mean concentration of oestradiol between -20 and $0 \mathrm{~h}$ was significantly higher than during the period 4-20 h after the maximum $\mathrm{LH}$ concentration (Student's $t$ test for 2 groups of unpaired data, $P<0.001$ ). The LH values between -2 and $+4 \mathrm{~h}$ inclusive were significantly higher than baseline concentrations $(P<0.001)$. FSH values between -2 and $+4 \mathrm{~h}$ were also significantly higher $(P<0.001)$ than those for periods of $10 \mathrm{~h}$ before or after this time. However, FSH values $16-30 \mathrm{~h}$ after the LH peak were also significantly raised $(P<0.001)$ compared to the period from +4 to $+14 \mathrm{~h}$. 


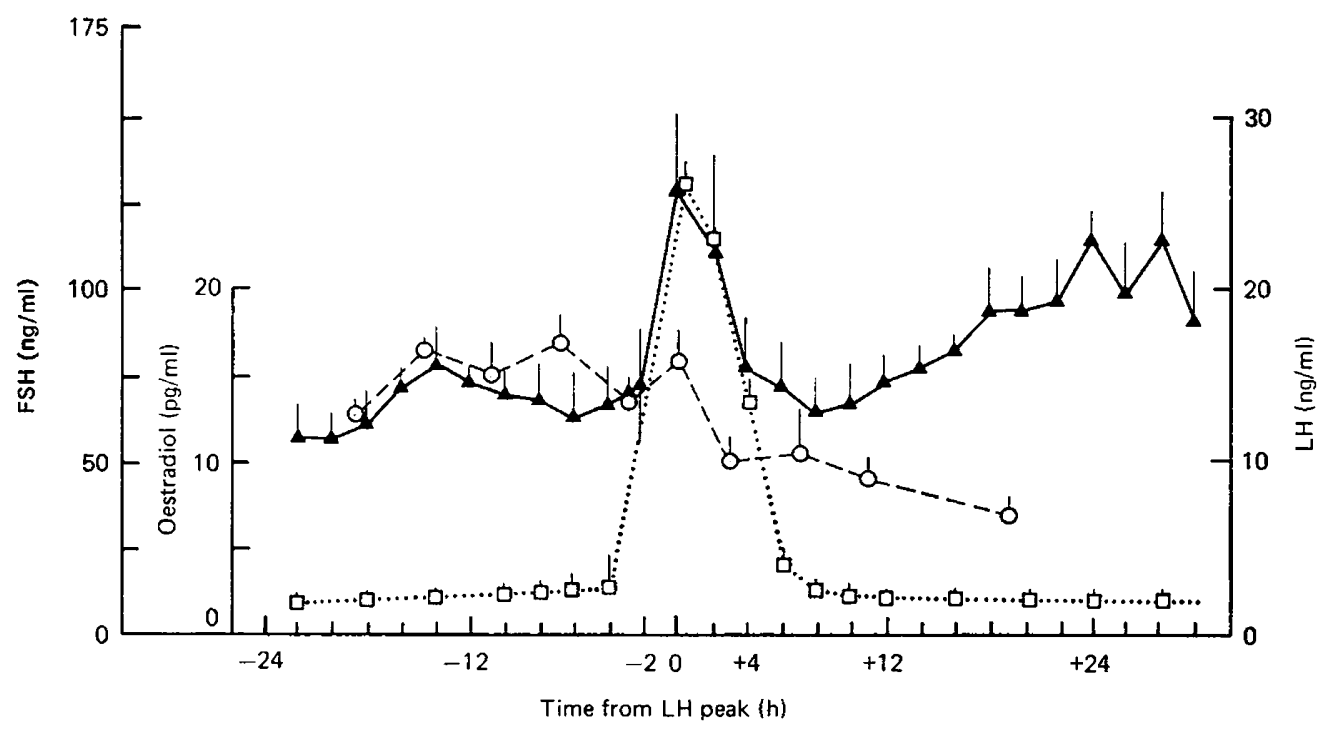

Text-fig. 1. Mean plasma concentration ( \pm s.e.m.) of LH ( $\square$ ), FSH ( $\Delta$ ) and (oestradiol (O) for 6 heifers during the oestrous period in relation to the maximum concentration of $\mathrm{LH}(0 \mathrm{~h})$.

\section{Discussion}

The second peak of FSH has not previously been reported, probably because of infrequent sampling. The pattern of plasma hormone concentrations around oestrus in heifers is similar to that reported for ewes (Pant, Hopkinson \& Fitzpatrick, 1977), although the FSH values were more variable in heifers.

It has been well established that the synchronous surges of LH and FSH are involved in ovulation and formation of the corpus luteum (Schwartz \& McCormack, 1972), but there is less understanding about the function of the second peak of FSH. In ewes and cows it occurs $24 \mathrm{~h}$ after the LH peak, i.e. around the time of ovulation (Kiddy \& Odell, 1969; Schams \& Karg, 1969), but the cause of the peak has not been determined. Plasma oestradiol concentrations are elevated before the dual surge of LH and FSH, but the concentration of this steroid has declined before the surge of FSH alone. Synthetic gonadotrophin-releasing hormone will release LH and FSH in heifers (Akbar et al., 1974), but the evidence presented here suggests that there is a separate mechanism for the release of FSH without LH.

I thank the Animal Health Trust for a Wooldridge Fellowship; the A.R.C. for further financial support: Professor R. J. Fitzpatrick for encouragement and facilities; Sandie Midmer for technical assistance; NIAMDD, Bethesda, U.S.A., for radioimmunoassay materials; Dr R. B. Snook for the LH antibody; and Dr L. E. Reichert for purified gonadotrophins.

\section{References}

Akbar, A.M., Reichert, L.E., Dunn, T.G., KaltenBACH, C.C. \& NisWENDER, G.D. (1974) Serum levels of follicle stimulating hormone during the bovine estrous cycle. J. Anim. Sci. 39, 360-371.

Derivaux, J., Ectors, F., Hendrick, J.C. \& FranchiMONT, P. (1974) Determination de la FSH plasmatique chez les bovines. Annls Enodcr. 35, 614-621.
Dobson, H. (1978) Radioimmunoassay of FSH in the plasma of post-partum dairy cows. $J$. Reprod. Fert. 52, 45-49.

Dobson, H. \& Dean, P.D.G. (1974) Radioimmunoassay of oestrone, oestradiol-17 $\alpha$ and $-17 \beta$ in bovine plasma during the oestrous cycle and last stages of pregnancy. $J$. Endocr. 61, 479-486. 
Dobson, H., Cooper, M.J. \& FurR, B.J. (1975) Synchronization of oestrus with I.C.I. 79939, an analogue of prostaglandin $F_{2 \alpha}$ and associated changes in plasma progesterone, oestradiol-17 $\beta$ and $L H$ in heifers. J. Reprod. Fert. 42, 141-144.

KIDDY, C.A. \& ODELL, W.A. (1969) Radioimmunoassay of blood LH at estrus and ovulation in cattle. $J$. Anim. Sci. 29, 192, Abstr.

Pant, H.C., Hopkinson, C.R.N, \& Fitzpatrick, R.J. (1977) Concentrations of oestradiol-17 $\beta$, progesterone, luteinizing hormone and follicle stimulating hormone in the jugular venous plasma of ewos during the oestrous cycle. J. Endocr. 73, 247-255.

Schams, D. \& KARG, H. (1969) Radioimmunoassay of LH in bovine blood. Acta endocr., Copenh. 61, 96, Abstr.

Schams, D. \& Schallenberger, E. (1976) Heterologous radioimmunoassay for bovine follicle stimulating hormone and its application during the oestrous cycle in cattle. Acta endocr., Copenh. 81, 461-473.

SCHWARTZ, N.B. \& MCCORMACK, J.R. (1972) Reproduction: gonadal function and its regulation. $A$. Rev. Physiol. 34, 425-534.

Received 17 March 1977 